\title{
Expression of Recombinant Fusion Protein from Local Isolate of Newcastle Disease Virus and Antibody Response to Recombinant Fusion Protein in Broiler Chickens Post-Vaccination
}

\author{
R.W. Astuti ${ }^{1}$, N. Wijayanti ${ }^{2}$ and A. Haryanto ${ }^{3, *}$ \\ ${ }^{1}$ Research Center for Biotechnology Studies, Universitas Gadjah Mada, Jl. Teknika Utara \\ Barek, Depok, Sleman, Yogyakarta 55281 - Indonesia \\ ${ }^{2}$ Animal Physiology Laboratory, Faculty of Biology, Universitas Gadjah Mada, Jl. Teknika \\ Selatan, Sekip Utara, Bulaksumur, Yogyakarta 55281 - Indonesia \\ 3, Department of Biochemistry and Molecular Biology, Faculty of Veterinary Medicine, \\ Universitas Gadjah Mada, Jl. Fauna 2, Karangmalang, Yogyakarta 55281 - Indonesia \\ *Corresponding E-mail: arisharyanto@ugm.ac.id.
}

Received October 16, 2019; Accepted May 15, 2020

\begin{abstract}
ABSTRAK
Penelitian ini bertujuan untuk mengekspresikan dan memurnikan protein Fusion (F) rekombinan virus Newcastle Disease Virus (ND) yang berasal dari isolat lokal di Galur, Kulon Progo, Indonesia (0663/04/2013) yang telah diinsersikan di dalam plasmid rekombinan pBT7-N-His F, serta mempelajari respon antibodi dalam serum broiler yang telah disuntikkan dengan protein $\mathrm{F}$ rekombinan murni yang dibandingkan dengan kelompok broiler yang telah divaksinasi dengan vaksin ND inaktif komersial dan dibandingkan dengan kelompok broiler kontrol yang tidak divaksinasi apapun. Hasil penelitian menunjukkan bahwa protein $\mathrm{F}$ rekombinan virus ND telah berhasil diekspresikan, dimurnikan dan divisualisasikan sebagai protein $\mathrm{F}$ rekombinan spesifik dengan berat molekul $28 \mathrm{kDa}$ dengan metode SDS-PAGE dan pewarnaan Coomassie Brilliant Blue serta dengan metode Westernblotting. Protein F rekombinan murni kemudian disuntikkan pada kelompok broiler perlakuan untuk mengukur respon antibodi yang diproduksi pada serum broiler. Hasil uji dengan indirect ELISA menunjukkan bahwa produksi antibodi terlihat tinggi pada kelompok broiler yang divaksinasi protein $\mathrm{F}$ murni jika dibandingkan dengan kelompok perlakuan dan kontrol lainnya. Protein $\mathrm{F}$ rekombinan tersebut memiliki potensi tinggi untuk dikembangkan sebagai kandidat vaksin rekombinan ND in aktif. Penghilangan bagian 6x His-tag protein $\mathrm{F}$ rekombinan perlu dilakukan untuk mendapatkan respon antibodi yang lebih tinggi jika dibandingkan dengan pemberian vaksin ND komersial yang beredar di pasaran.
\end{abstract}

Kata kunci : respon antibodi, broiler, protein $F$ recombinan, $N D V$, vaksinasi

\begin{abstract}
This research aimed to express and purify the recombinant Fusion (F) protein of Newcastle Disease Virus (NDV) from a local isolate in Galur, Kulon Progo, Indonesia (0663/04/2013) from recombinant vector plasmid $\mathrm{pBT} 7-\mathrm{N}-\mathrm{His} \mathrm{F}$, and to study the antibody response in the broiler sera which were injected with pure recombinant $\mathrm{F}$ protein compared with treated broilers that were vaccinated with commercial inactive NDV vaccines and control broilers without vaccination. The results showed that the recombinant F protein of NDV was successfully expressed, purified and visualized by SDS-PAGE with
\end{abstract}


Coomassie Brilliant Blue staining and Westernblotting methods as a specific recombinant $\mathrm{F}$ protein with a molecular weight of $28 \mathrm{kDa}$. The pure recombinant $\mathrm{F}$ protein then was injected into broilers to determine the antibody response in broiler serum. Indirect ELISA showed that the production of antibodies was high in F protein vaccinated groups in comparison with other treated and control groups. The recombinant $\mathrm{F}$ protein has potential to be developed as a recombinant vaccine candidate after truncating the 6x His-tag part to obtain higher antibody respond if compared with antibody production in broiler serum post vaccinated with some commercially available broiler vaccines.

Keywords: antibody response, broiler, recombinant $F$ protein, NDV, vaccination

\section{INTRODUCTION}

Newcastle Disease Virus (NDV) is an Avian paramyxovirus type I, which belongs to the Genus Avulavirus, Family Paramyxoviridae, and is a virulent infectious agent in poultry (Mayo, 2002a, Mayo, 2002b, Alexander and Senne, 2008). The NDV genome encodes six viral proteins, namely: RNA-directed RNA Polymerase (L) gene, Hemagglutinin-Neuraminidase (HN) gene, Fusion (F) gene, Matrix (M) gene, Phosphoprotein (P gene), and Nucleocapsid (NP) gene (Alexander $e t$ al., 1999). Hemagglutinin-Neuraminidase and Fusion glycoproteins contained in the NDV envelope play a significant role in the virus virulence and pathogenicity. The two proteins can induce protective immunity; however, $\mathrm{F}$ protein provide high immunogenicity a better protective level compared with $\mathrm{HN}$ protein. It has a greater role in providing protection against NDV infection (Muelemans et al., 1986.; Ogawa et al., 1990.; Umino et al., 1990; Nagi et al., 1991; Miller et al., 2009; Kumar et al., 2011). NDV infection can lead to a serious economic loss in poultry farming worldwide Ashraf and Shah, 2014).

Based on its virulence or pathogenicity, NDV can be classified into three types: lentogenic (low virulent), mesogenic (moderate virulent), and velogenic (high virulent). The classification of local isolates of the NDV pathotype is essential. Local isolates of NDV pathotype can be classified by conducting two simple procedures, namely, Reverse Transcriptase Polymerase Chain Reaction (RT-PCR) and Restriction Fragment Length Polymorphism (RFLP) using endonuclease enzyme Hin fI restriction (Haryanto et al., 2016a).

One of the strategies to prevent and inhibit the dissemination of NDV is by conducting a vaccination program. The ND program is conducted by injecting poultry with low-virulent live ND and inactive vaccine. The aim of the vaccination program in broiler chicken farms is to increase the immunity by inducting humoral immunity without influencing the efficiency of meat production (Westbury et al., 1984; Czifra et al., 1998; Haryanto et al., 2016b). Prevailing strategies to prevent ND include inactive vaccines and attenuated vaccines. However, there is still a possibility of failure in the strategy to obtain protective humoral immunity (Elazab et al., 2010).

Fusion (F) and $\mathrm{HN}$ proteins are the main antigens that can evoke major protective immune response to NDV (Kapczynski and King, 2005, Kattenbelt et al., 2006, Yin et al., 2006). Fusion protein functions as a fusion protein and contributes to the process of NDV adsorption (White et al., 2008). Vaccines that are produced based on commonly found NDV isolates confer better protection against the infectious agent and can reduce viral shedding (Miller et al., 2013). Developing recombinant vaccines based on the $F$ protein of locally-isolated NDV recombinants could be a more effective approach to control Newcastle Disease (Mase et al., 2011; Kang et al., 2016).

This research studied the expression of the local-isolate NDV F protein, which plays a role in neutralizing and inducing immune response in form of antibodies against NDV (Lamb and Jadetzky, 2007). A previous study has succeeded in the phylogenetic analysis and subcloning of the encoding gene of the NDV F protein from a local isolate from Galur, Kulon Progo, Indonesia $(0663 / 04 / 2013)$ on pBT7-N-His plasmid (Wulanjati et al., 2018). This research was conducted to express and purify the NDV F protein recombinant from the local isolate. After the pure protein has been obtained, it will be produced and injected in broiler chicken to evaluate the production of anti-F recombinant protein antibodies by employing the indirect ELISA method. The recombinant $F$ protein can be developed as a recombinant vaccine candidate for 
NDV. Therefore, the aim of this research was to express and purify the recombinant Fusion (F) protein of Newcastle Disease Virus (NDV) from a local isolate in Galur, Kulon Progo, Indonesia $(0663 / 04 / 2013)$ from recombinant vector plasmid pBT7-N-His F, as well as study the antibody response in the broiler sera which were injected with pure recombinant $\mathrm{F}$ protein which compared between broiler in control group with broiler in treated group which were vaccinated with commercial inactive NDV vaccines.

\section{MATERIALS AND MTEHODS}

\section{Sample Preparation}

The sample used in this research is NDV recombinant $\mathrm{F}$ protein produced in Escherichia coli BL21 (DE3) bacteria. The encoding gene of NDV F protein was isolated from native chicken isolate Galur, Kulon Progo, Indonesia (0663/04/2013) which has been previously characterized for its pathotype by Haryanto et al. (2015). The recombinant $\mathrm{F}$ protein encoding gene of NDV has been subcloned into the pBT7-N-His expression plasmid (Bioneer, South Korea) by Wulanjati et al. (2018) as presented in Figure 1.

\section{Plasmid Isolation}

The plasmid isolation was conducted using the Presto ${ }^{\text {TM }}$ Mini Plasmid Kit (Geneaid Biotech Ltd, Taiwan). The DNA plasmid was digested using the Eco RI enzyme and separated on an agarose electrophoresis gel 1.5\%.

\section{Expression and Purification of NDV Recombinant F Protein}

The expression of NDV recombinant $F$ protein was conducted using the Accu Rapid ${ }^{\mathrm{TM}}$ Protein Expression Kit (Bioneer, South Korea). Next, the $6 \mathrm{x}$ histidine-tagged recombinant $\mathrm{F}$ protein was purified using the Ni-NTA Spin Kit (Qiagen, USA) in the native condition. The sample of recombinant $F$ protein was concentrated using a Nanosep centrifugal device (Pall Corporation, USA) according to the instructions suggested by the manufacturer. The expressed protein was separated using SDS-PAGE. The protein was visualized using Coomassie Brilliant Blue staining and Western blotting. The concentration of expressed recombinant $\mathrm{F}$ protein was then quantified by using Spectrophotometer DU-65 (Beckman, USA).

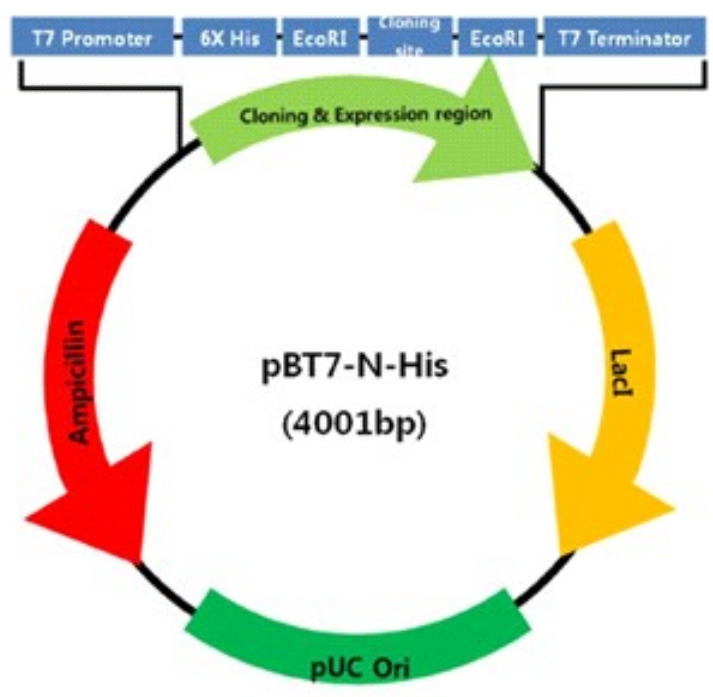

*Cloning \& Expression region

GAAATTAATACGACTCACTATAGGGGAATTGTGAGCGGATAACAATTCCCCTCTAGAAATAATTTTGTTTAA

CTTTAAGAAGAGATATACATGCATCATCATCATCATCATGAATTCAGCCAGCAAGACAGCGAT/ATCACC

TGTAAGTCGGACGAATTCAGCAGCGGCCTGGTGCCGCGCGGCAGCIFACCGCTGAGCAATAACTAGCATAAC

Figure 1. Construction of the vector recombinant plasmid pBT7-N-His-Fusion NDV 


\section{Westernblotting}

The NDV recombinant $F$ protein was visualized by Westernblotting using the $6 \mathrm{x}$ Histidine Epitope Taq Antibody (Invitrogen, Canada) as the primary antibody (dilution 1: 2.000) and goat anti-mouse IgG Affinity Purify (dilution 1: 15.000) (Thermo Scientific, USA) as the secondary antibody. The substrate was 1Step $^{\text {TM }}$ NBT/BCIP (nitro-blue tetrazolium chloride and 5-bromo-4-chloro-3'indolyphosphate p-toluidine salt) (Thermo Scientific, USA).

\section{Broiler Chickens Vaccination}

To study the immunogenicity of the expressed recombinant $\mathrm{F}$ protein, 40 broiler chickens were vaccinated. The chickens were divided into four groups: A, B, C, and D. Each group consisted of ten chickens. Group A consisted of ten chickens that were vaccinated with pure recombinant $\mathrm{F}$ protein obtained from expression $(10 \mu \mathrm{g} / \mathrm{chicken})$ emulated with complete and incomplete Freund's adjuvant (Sigma, USA) that consist of $0.15 \mathrm{ml}$ mannide monooleate and $0.85 \mathrm{ml}$ paraffin oil in total volume of $1 \mathrm{ml}$. Group B consisted of ten chickens that were vaccinated with commercial inactive ND vaccine that was manufactured by SHS company (killed NDV Vaccine). Group C consisted of ten chickens that were injected with adjuvant. Group D was the control group, which consisted of ten unvaccinated chickens. The immunogenicity study to measure the antibody titer on the broiler chicken serum was conducted via two administrations of the vaccine. The first vaccination was administered to 14-day-old chickens via subcutaneous injection of pure recombinant $\mathrm{F}$ protein, which was emulsified in Complete Freund's Adjuvant (Sigma, USA). The second vaccination (booster) was administered after the chickens were 28 days old. The injection of pure recombinant $\mathrm{F}$ protein was administered using Incomplete Freund's Adjuvant (Sigma, USA).

\section{Sampling of Broiler Chicken Sera}

Blood sampling was conducted through vena brachialis when the chickens were 28 days old or before the second vaccination (booster). The second blood sample was collected from the serum of 40 chickens using Vaccutainer Clot Activator (GP Vacutube, China) on day 36, which was the last day of the research. The sera were stored at $-20^{\circ} \mathrm{C}$ before being used for indirect
ELISA.

\section{Indirect ELISA}

Microplates (Nunc Maxisorp, Denmark) were coated with $10 \mu \mathrm{g} / \mathrm{ml}$ recombinant F protein antigen. The conjugate and primer antibody was determined by previously conducting checker board titration. The sample serum was diluted at a ratio of 1:50. The dilution of the secondary antibody was Goat Anti-Chicken $\operatorname{IgY}(\mathrm{H}+\mathrm{L})$ Alkaline Phosphatase (Novex, USA) $100 \mu \mathrm{L} /$ well at a 1:5000 ratio. 4-Nitrophenylphosphate dinatriumsalz substrate (Merck, Germany) 100 $\mu \mathrm{L} /$ well $(1 \mathrm{mg} / \mathrm{mL}$ in substrate buffer). Optical Density (OD) of the broiler chicken serum was read using an ELISA reader (Zenix, USA) at a wave length of $405 \mathrm{~nm}$ in compared with standard curve.

\section{Statistical Analysis}

ELISA data for the serum samples are presented as the average \pm SD. The significantly different data from various groups that were vaccinated at various time points were evaluated and analyzed using Two-way ANOVA. A comparison test was conducted using Tukey's test, and $\mathrm{p}$-values $<0.05$ were considered significant. The statistical analysis was conducted using the Prism 6.0 computer software (Graphpad Software La Jolla, CA, USA).

\section{RESULTS}

\section{Isolation and Verification of pBT7-N-His-F Recombinant Plasmid:}

Plasmid isolation from Escherichia coli BL21 (DE3) bacteria carrying pBT7-N-His-F recombinant plasmid was conducted using Kit Presto Mini Plasmid (Geneaid Biotech Ltd, Taiwan). The DNA of the isolated plasmid was digested using the Eco RI restriction enzyme. A screening was conducted to determine the presence of the recombinant plasmid in the growing $E$. coli colony by isolating the DNA of the pBT7-N-His plasmid recombinant, which had been inserted with the F-protein-encoding gene with a size of $4.601 \mathrm{bp}$, as shown in Figure 2. Lines 2, 4, 6 showed the results of the plasmid isolation of different recombinant $\mathrm{F}$ bacteria colonies. The plasmid, which was separated into agarose gel electrophoresis, indicates three bands of DNA. The target gene on the transformed $E$. coli plasmid was determined by digesting the pBT7-N-His plasmid using the restriction enzyme 


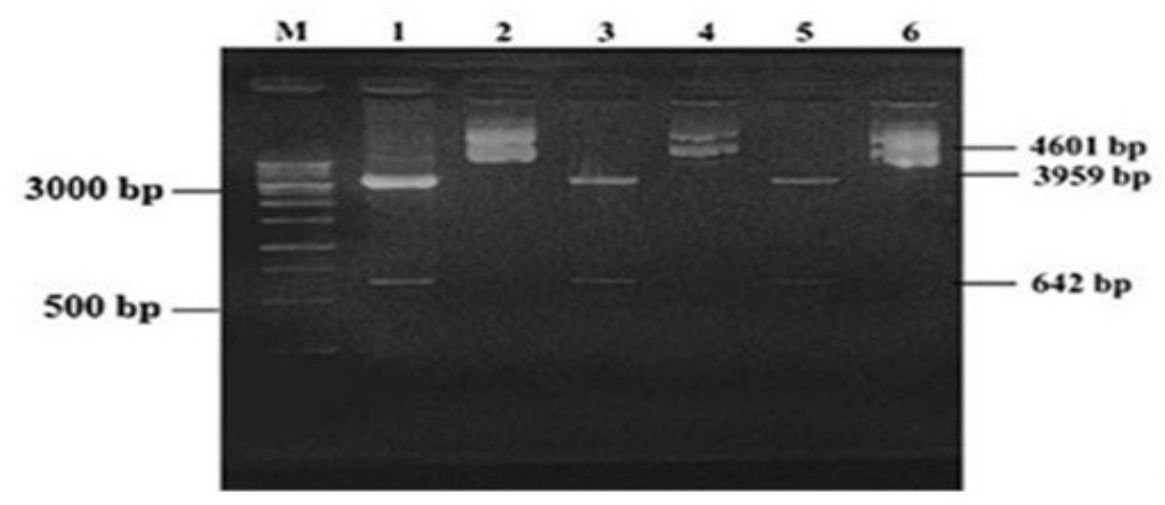

Figure 2. Electrophoresis of pBT7-N-His-Fusion NDV recombinant plasmid digested with Eco RI enzyme on $1.5 \%$ agarose gel with $1 \mathrm{~kb}$ marker DNA. The resulting size of the digested plasmid is 642 bp and 3959 bp. (M). Marker DNA ladder, (1). Recombinant plasmid pBT7-N-His-F that is digested with Eco RI enzyme from clone-1 (C-1) plasmid isolation, (2). Intact pBT7-N-His-F recombinant plasmid from $\mathrm{C}-1$ plasmid isolation, (3). Recombinant plasmid pBT7-N-His-F digested with Eco RI enzyme from clone-2 (C-2) plasmid isolation, (4). Intact pBT7-N-His-F recombinant plasmid from C-2 plasmid isolation, (5). Recombinant plasmid pBT7-N-His-F digested with Eco RI enzyme from clone-3 (C-3) plasmid isolation, (6). Intact pBT7-N-His-F recombinant plasmid from C-3 plasmid isolation.

Eco RI in Figure 2. Electrophoresis of the digested recombinant plasmid is shown in Fig. 2, lines 1,3 , and 5, there are two bands that exhibit sizes of $3.959 \mathrm{bp}$ and $642 \mathrm{bp}$. Meanwhile, lines 2, 4 , and 6 are undigested intact plasmid as the comparative plasmid. Before the digestion of DNA plasmid by Eco RI enzyme, the electrophoresis results of recombinant plasmid pBT7-N-His showed two forms of plasmid DNA, namely a circular relaxed plasmid DNA which faster moving into agarose gel and a supercoiled DNA plasmid which slower moving in agarose gel.

There is only one fragment of DNA, which is shown in the undigested intact recombinant DNA plasmid. The size of the F-protein-encoding gene, which was obtained by digestion using the Eco RI enzyme, was $642 \mathrm{bp}$, while the size of the pBT7-N-His plasmid, which did not contain the F gene, was $3.959 \mathrm{bp}$. This result shows that the $\mathrm{F}$ gene (642 bp) had been successfully inserted into the pBT7-N-His plasmid.

\section{Expression of NDV Recombinant F Protein.}

The identification and verification results, which indicates the orientation of the NDV F insertion gene, were followed by the in vitro expression of the $F$ protein using a cell-free protein expression kit. The expression of the recombinant $\mathrm{F}$ protein was visualized via SDS-
PAGE electrophoresis followed by Coomassie Brilliant Blue (CBB) staining so that the protein bands could be observed based on certain sizes, which were comparable to protein markers. The size of the expressed protein was calculated by counting the nucleotides of the recombinant $\mathrm{F}$ gene from the start codon (ATG) until the stop codon (TGA) on the plasmid to obtain the length of the gene as 699 nucleotides. The size of 699 nucleotides was converted into an amino-acid average molecular weight and visualized by the SDS-PAGE gel using Coomassie Brilliant Blue staining is shown in Figure 3. The figure shows that in lines 1,2, 3 which represents the NDV recombinant $\mathrm{F}$ protein, there was a $25.6 \mathrm{kDa}$ protein band.

\section{Purification of NDV Recombinant F Protein.}

The expressed recombinant $F$ protein was purified using the Ni-NTA Spin Kit. The proteins underwent electrophoresis on an SDS-PAGE 12\% gel and visualization using Coomassie Brilliant Blue staining. The weight of recombinant $F$ protein molecule was added with $6 \mathrm{x}$ histidine tags (2-3 $\mathrm{kDa})$ in its $\mathrm{N}$-terminus, so the overall molecular weight of the recombinant $\mathrm{F}$ protein is around $28 \mathrm{kDa}$. The visualization of the SDSPAGE gel using Coomassie Brilliant Blue staining is shown in Figure 4. The figure shows that in lines 1, 2, 3 which represents the purified NDV 


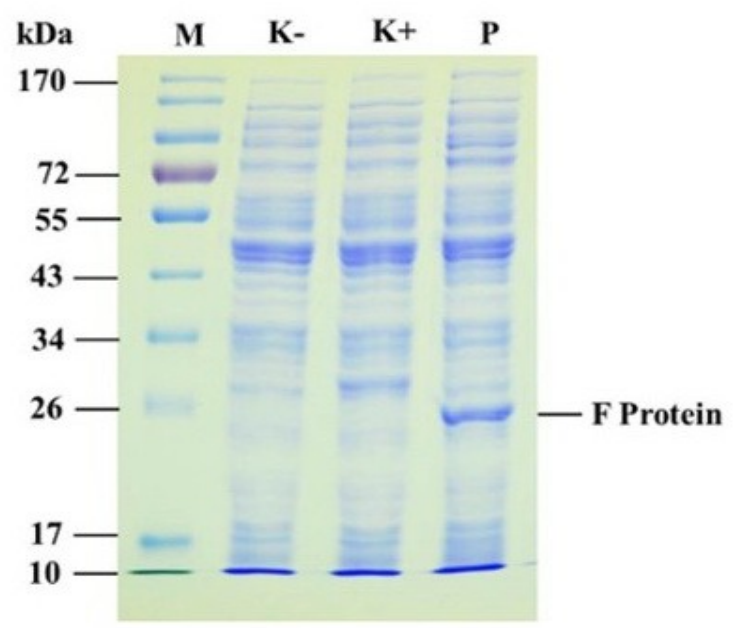

Figure 3. Electrophoresis of expressed NDV recombinant $\mathrm{F}$ protein on $12 \%$ SDS-PAGE gel with Coomassie Brilliant Blue staining. (M) Marker protein, (K-) Negative control, $(\mathrm{K}+$ ) Positive control protein $(28 \mathrm{kDa}),(\mathrm{P}) \mathrm{NDV}$ recombinant $\mathrm{F}$ protein with a size of $25.6 \mathrm{kDa}$ from $\mathrm{pBT} 7-\mathrm{N}-\mathrm{His}-\mathrm{F} \mathrm{C1}$ recombinant plasmid

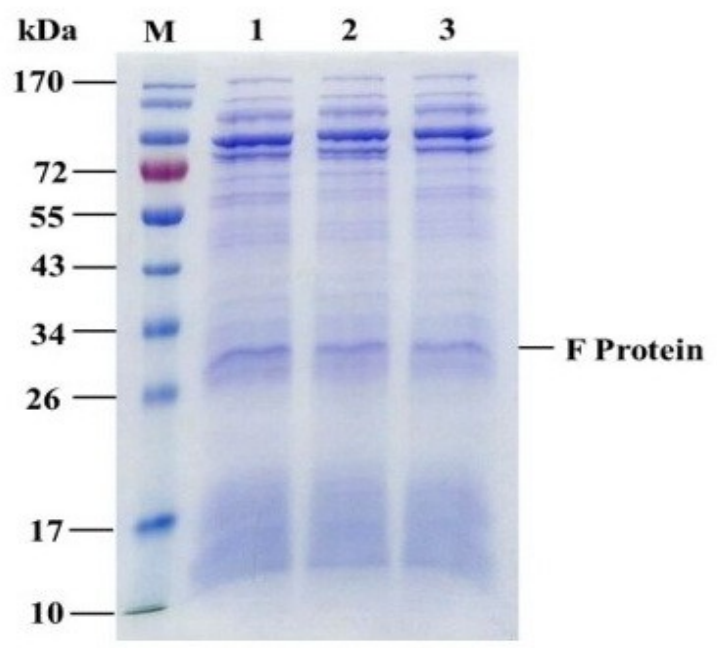

Figure 4. Electrophoresis of NDV recombinant $\mathrm{F}$ protein after purification on $12 \%$ SDS-PAGE with Coomassie Brilliant Blue staining. (M). Marker protein, (1). Expressed Protein from C-1 recombinant plasmid, (2). Expressed protein from C-2 recombinant plasmid, (3). Expressed protein from C-3 recombinant plasmid.

recombinant $\mathrm{F}$ protein as a thick protein bands with a size of $28 \mathrm{kDa}$.

\section{Westernblotting}

Purified recombinant $F$ protein was analyzed further using Westernblotting. The expressed $\mathrm{F}$ protein which had undergone electrophoresis on a SDS-PAGE $12 \%$ was transferred from the gel to a
Polyviniylidene Difluoride (PVDF) membrane. The NDV recombinant $F$ protein with a $6 x$ Histag, which plays the role of an antigen, was reacted immunologically with anti-Histaq antibody (6x His Epitope Tag Antibody). The result of the Westernblotting is shown in Figure 5. The figure indicates that the recombinant $\mathrm{F}$ protein binds and reacts positively with $6 \mathrm{x}$ His 


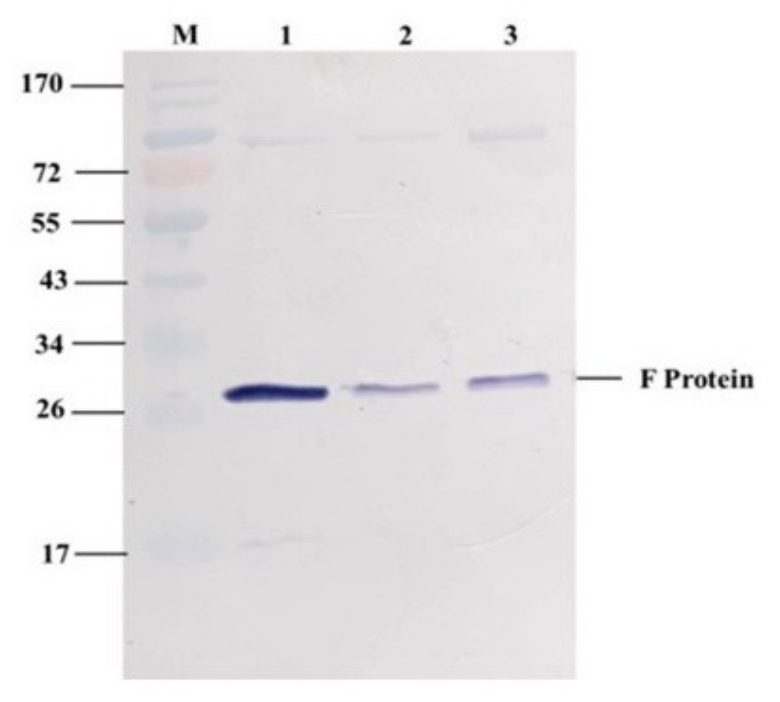

Figure 5. Western blot of the pure NDV recombinant $F$ protein. (M) Marker protein. (1). NDV recombinant $\mathrm{F}$ protein from $\mathrm{C}-1$ clone, (2). NDV recombinant $\mathrm{F}$ protein from $\mathrm{C}-2$ clone, (3). NDV recombinant $\mathrm{F}$ protein from $\mathrm{C}-3$ clone.

Epitope Taq Antibody (Invitrogen, USA). Westernblotting using 6x His Epitope Taq Antibody (Invitrogen, USA) is required to verify the result from the SDS-PAGE of the purified NDV recombinant $F$ protein. Therefore, in this research, the NDV recombinant $\mathrm{F}$ protein was successfully expressed and purified. The visualization using SDS-PAGE, Coomassie Brilliant Blue staining and Westernblotting indicate that the NDV recombinant $F$ protein has a molecular weight of $28 \mathrm{kDa}$. The purified ND recombinant $F$ protein is a candidate for an ND recombinant vaccine, which is ready to be studied further in broiler chickens.

\section{Measurement of Recombinant F Protein Concentration}

The concentration of NDV recombinant $\mathrm{F}$ protein that had been successfully expressed was measured using the Bio-Rad (Biorad protein assay) method. This calculation was performed by measuring the absorbance value of the optical density (OD) of the recombinant $F$ protein samples at a wavelength of $595 \mathrm{~nm}$ using a spectrophotometer. Based on the calculation, the concentration of the recombinant $F$ protein obtained from expression was $0.6527 \mu \mathrm{g} / \mu \mathrm{L}$.

\section{Injection and Vaccination of Recombinant $F$ Protein in Broiler.}

Injection and vaccination in broiler chickens were performed twice, namely, on the 14th day and the $28^{\text {th }}$ day. A total of 40 broilers were divided into four groups, each of which consisted of 10 broilers. The first group (F protein group) was injected with pure recombinant protein $\mathrm{F}$ (10 $\mu \mathrm{g} / \mathrm{broiler}$ ). The second group (S vaccine group) was vaccinated with the inactive NDV S-vaccine. The third group (adjuvant group) was injected with adjuvant solutions. The fourth group was not vaccinated during the 36 days of broiler maintenance. On the $28^{\text {th }}$ and $36^{\text {th }}$ days, blood was collected from all forty broilers in the four groups, and their sera were separated for serological testing by measuring the titer of the recombinant anti protein $\mathrm{F}$ antibody using the indirect ELISA method.

\section{ELISA}

Production of NDV recombinant anti-protein $\mathrm{F}$ antibodies was determined using the indirect ELISA test with the average optical density value that was read by the ELISA reader at a wavelength of $405 \mathrm{~nm}$, as shown in Figure 6. It showed the antibody titer, represented as the mean $\pm \mathrm{SD}$, from chickens that were immunized with the NDV recombinant $F$ protein; those immunized with the $\mathrm{S}$ vaccine, which is an inactive commercial vaccine; those administered the adjuvant; and the non-injected control. The antibody titer results from 28-day chicken serum samples, which were treated 14 days after the first 


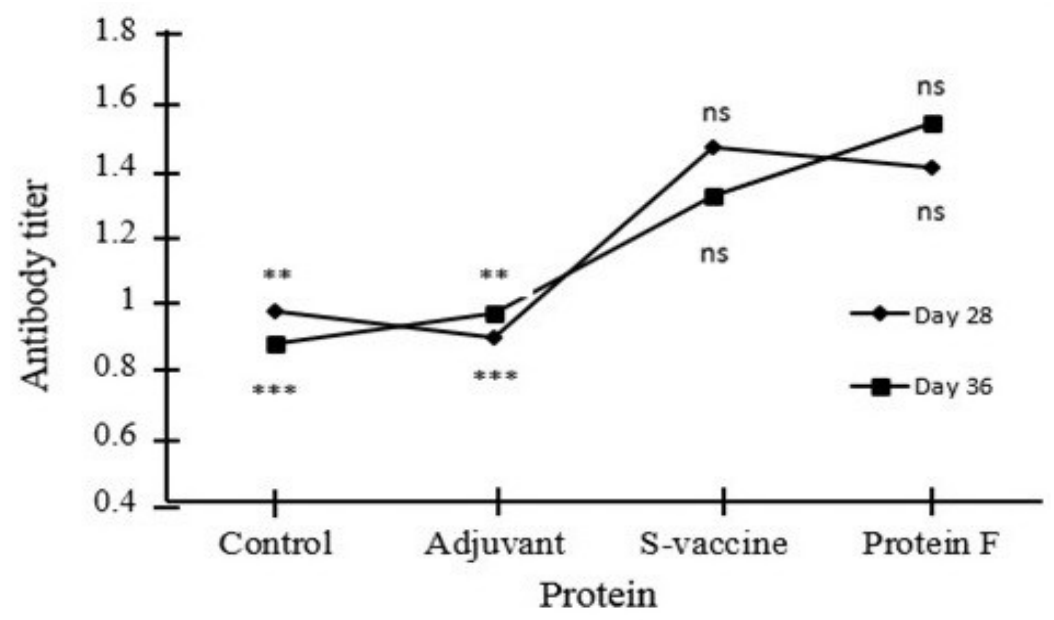

Figure 6. The antibody response of broiler chicken sera against ND vaccines in different groups by indirect ELISA which was analyzed by two-way ANOVA followed by Tukey's multiple comparison test. $(n s)$ is not significant, $(*)$ is a significant difference of $\mathrm{F}$ protein $(36$ days), $(* *)$ is a significant difference of $\mathrm{F}$ protein ( 36 days), $(* * *)$ is a significant difference of $\mathrm{F}$ protein (36 days).

vaccination, and from 36-day-old chicken serum samples, which were treated 8 days after the booster vaccination. The antibody titers, represented as the mean $\pm \mathrm{SD}$, for the chickens vaccinated with the $F$ protein vaccine, $S$ vaccine (inactive commercial NDV vaccine), adjuvant and controls were $1,393 \pm 0.491,1.454 \pm 0.299,0.886$ \pm 0.145 , and $0.965 \pm 0.162$, respectively. Following the booster vaccination, the antibody titer $\pm \mathrm{SD}$ for the chickens vaccinated with the $\mathrm{F}$ protein vaccine, $\mathrm{S}$ vaccine (inactive commercial NDV vaccine), adjuvant and control were 1,525 \pm $0.332,1.308 \pm 0.150,0.961 \pm 0.101$, and $0.869 \pm$ 0.083 , respectively. The antibodies produced in the highest amounts were the post-booster antibodies of the recombinant $\mathrm{F}$ protein because of responses from memory cells and the protein injection with the adjuvant.

The post-booster humoral immune response of the chickens that were injected with the recombinant $\mathrm{F}$ protein of NDV was the highest compared to the other three groups, as seen in Figure 6. There was no significant difference ( $p>$ 0.05 ) between broiler chickens group which were vaccinated by post-booster protein $\mathrm{F}$ recombinant with the broiler chickens group which were vaccinated by $\mathrm{S}$ vaccine within 28 days. . The broiler chickens group which were vaccinated by post-booster recombinant $\mathrm{F}$ protein also showed no significant difference compared to the broiler chickens group were vaccinated by $\mathrm{S}$ vaccine within 36 days $(\mathrm{P}>0.05)$. These data suggested that vaccination by the recombinant $F$ protein of NDV in broiler chickens provided humoral immune responses and produced the same level of anti-NDV antibodies as high as broiler chickens group which were vaccinated by commercially inactive vaccines. Fig. 6 also showed that humoral immune responses from vaccination with postbooster recombinant $\mathrm{F}$ protein showed a significant difference compared with the control group and the broiler group that was injected with adjuvant alone. It showed that the antibody titer value of broiler chickens that were vaccinated with post-booster NDV recombinant $\mathrm{F}$ protein compared with the adjuvant-injected broiler group (28 day) was significantly different $(* * * \mathrm{P}<0.05)$. The group of broiler chickens that was injected with post-booster NDV recombinant $F$ protein showed significant differences compared to the group of adjuvant-injected chickens (36 day) (** $\mathrm{P}<0.05)$. The humoral immune response in the chicken group that was injected with the postbooster NDV recombinant $\mathrm{F}$ protein, compared with the control group (28 days), showed significant differences $(* * \mathrm{P}<0.05)$. Similarly, the humoral immune response in the group of broiler chickens that was injected with post-booster NDV recombinant $\mathrm{F}$ protein showed a significant difference compared with the control-group broilers ( 36 days) $(* * * \mathrm{P}<0.05)$. These Data were analyzed by using two-way ANOVA followed by Tukey's multiple comparison test. 


\section{DISCUSSION}

In this study, it was expressed the recombinant $\mathrm{F}$ protein of NDV from the recombinant plasmid vector $\mathrm{pBT} 7-\mathrm{N}-\mathrm{His}$, which have been previously prepared by Wulanjati et al (2018) by subcloning of NDV F protein encoding gene from local isolate in Galur, Kulon Progo, Indonesia (0663/04/2013) into the pBT7-N-His expression vector. The design of recombinant plasmid vector is presented in Figure 1.

After purification and concentration, we obtained pure recombinant $\mathrm{F}$ protein of NDV with a molecular weight of $28 \mathrm{kDa}$, as visualized by Coomassie Brilliant Blue staining (Fig. 4) and Westernblotting (Fig. 5). The broiler group that was injected with recombinant $F$ protein showed the highest antibody titers compared with the other three groups; however, the high antibody titers in this group did not show a significant difference when compared with the broiler group that was vaccinated with commercially inactive NDV vaccines. However, the high antibody production in the broiler group that was injected with recombinant $F$ protein on days $28^{\text {th }}$ and $36^{\text {th }}$ showed a significant difference compared with antibody production in the broiler group that was vaccinated only with adjuvants and broilers in the control group (Figure 6).

Fusion protein is the antigen of NDV which is a significant factor in NDV virulence and it is capable of generating an immune response in the host (Alexander, 2004). NDV F protein is one of the important structural proteins that prevents infections by inhibiting viral fusion of host cell membranes (Miller et al., 2013). Plasmid expression vector pBT7-N-His-F, which has a sequence that codes a His-tag, was used in this study. This means that the $\mathrm{F}$ protein expressed from this plasmid vector is fused with $6 \mathrm{x}$ histidine amino acids at its N-terminus. The addition of $6 x$ histidine serves for purification of the recombinant $\mathrm{F}$ protein. 6x histidine will bind to the nickel on the beads contained in Ni-NTA, so that when the elution process is completed, the target protein can be separated from the other proteins. The expressed target protein will automatically carry six histidine amino acids as a histidine tag, while nontarget proteins will be lost in the washing process. The target protein will dissolve in the chelator solution, and the purified protein will elute with the elution buffer (Sambrook and Russel, 2001).

The size of the purified recombinant $\mathrm{F}$ protein exhibited a slightly increased molecular weight. This occurred because the target protein denaturation process prior to SDS-PAGE did not occur perfectly. Some proteins are stable under denatured conditions. However, if the target protein has not been fully denatured, it can affect the size of the molecular weight of the protein at the time of separation by the SDS-PAGE method. The purification of the protein with its 6x His-tag is the most commonly used affinity chromatography method for purifying target proteins with small molecular weights due to their strong ability to bind metal ions and good binding ability under denatured and native protein conditions. Under native protein separation conditions, protein folding processes may affect the molecular weight because native proteins will retain one or more disulfide bonds (GabercPorekar and Menart, 2001).

Protein denaturation is the process of changing the complete structure and characteristic shape of proteins due to the disruption of secondary, tertiary, and structural quaternary bonds. The biochemical function of proteins depends on their 3-dimensional shape and amino acid composition. Denaturation causes loss of biochemical activity in proteins. Protein denaturation does not affect the main components of protein, namely $\mathrm{C}, \mathrm{H}, \mathrm{O}$, and $\mathrm{N}$, although some proteins can be damaged during denaturation. Proteins may experience small changes in the structure inside when the denaturation process occurs (Stoker 2010).

Protein denaturation by heating cause the protein molecules to move very quickly during SDS-PAGE. Therefore, the protein molecules will be well-separated according to the molecular weight. Heating can damage hydrogen bonds and non-polar hydrophobic interactions. High temperatures can increase kinetic energy, so that the molecules of protein components move quickly and damage the bonds of these molecules. Heating will make the protein denatured so that the ability to bind the water decreases, it happens because heat energy causes non-covalent interactions in the natural structure of the protein was break, but did not break the peptide bond (Ophardt, 2003).

Mohan et al. (2006) stated that the recombinant-protein-based ELISA method is a better and faster alternative for detecting proteins in serum. Nucleoprotein $(\mathrm{N})$ and Hemagglutinin/ Neuraminidase $(\mathrm{H} / \mathrm{N})$ in NDV are often used to coat antigens in the ELISA test. However, El 
Zowalaty et al. (2011) argued that HN proteins have a low specificity, as many belong to other paramyxovirus viruses. In addition, HN protein cannot be well expressed in prokaryotic cells; therefore, it can increase misdiagnosis of serum samples. Arora et al. (2010) stated that in the NDV, the $F$ protein has a higher ELISA titer value than the HN protein. This suggests that $F$ protein has an important role for providing protection against NDV infection. The fusion protein encoding gene of NDV was selected as an insert into the expression vector because the gene encodes the $\mathrm{F}$ protein, which exhibits high immunogenicity and a better protective level compared to the HN protein (Kumar et al., 2011). Therefore, in this study, serological examination of blood samples of vaccinated broiler chickens was conducted by ELISA through coating the antigen of purified $F$ protein.

The ELISA test results (Figure 6) showed that vaccination of broiler chickens with recombinant $F$ protein of NDV from the local isolate and vaccinated broiler chickens by commercial inactive vaccine resulted in a better humoral immune response by producing higher immunoglobulin $\mathrm{G}$ ( $\mathrm{IgG}$ ) compared with the unvaccinated broiler control group and the broiler chickens group which were vaccinated only with adjuvant. The high titer of antibodies indicates that the immunogenicity of vaccinations with recombinant $\mathrm{F}$ protein and with commercial inactive vaccine is able to protect broiler chickens from natural infection with NDV. This humoral immune response plays a very important role in protecting broiler chickens against NDV infection. The data show that vaccination with recombinant $\mathrm{F}$ protein provides an equally high humoral immune response to broilers that were injected with commercial inactivated vaccines. This can be proved by the high value of antibody titers, as shown via ELISA (Maheswarappa et al., 2014). Live and inactive ND vaccine induce the formation of anti-NDV IgG antibodies in broiler chicken serum. Both types of vaccines stimulate the production of immunoglobulin $\mathrm{G}$ ( $\mathrm{IgG}$ ) by plasma cells. The rate of antibody formation IgG by live vaccine is lower compared with that by inactivated vaccine. The humoral immune response of IgG formation can be detected using the ELISA method (Chimeno et al., 2008).

Humoral response in the control broiler group and the broiler group that was injected with adjuvant alone indicated antibody formation; however, the antibody titer was lower than the antibody titer in the broiler chickens that were vaccinated with recombinant $F$ protein and the broiler group that was injected with commercial inactivated vaccine. This shows that in all groups of broiler chickens, there has been a natural infection by NDV; therefore, the immune response is detected through the formation of antibodies against NDV infection. It has been reported by Jeurissen et al., (2000) that the presence of infectious agents in the body induces the host to generate specific antibodies. These antibodies can be used as an indicator to observe the interaction between the poultry host with viral infectious agents through antibody formation reaction, either from the vaccination process or from the natural infection process. The formation of these antibodies is useful for neutralizing infections and can prevent attachment of viruses to receptors on the surface of host cells.

Recombinant $\mathrm{F}$ protein of NDV has been successfully expressed and well purified. The pure recombinant $\mathrm{F}$ protein has been injected in broilers to determine the antibody response in broiler serum. A higher antibody production was demonstrated in the broiler group that was vaccinated with the recombinant $F$ protein of the NDV and the broiler group injected with the commercial vaccine compared to the control broiler group and the broiler group that was injected with adjuvant. Statistical quantification showed that there was no significant difference in antibody production between the broilers vaccinated with recombinant $F$ protein and the broilers vaccinated with commercial vaccines. However, the high antibody production in the broiler group that was injected with recombinant $\mathrm{F}$ protein on days $28^{\text {th }}$ and $36^{\text {th }}$ showed a significant difference when compared with antibody production in the broiler group that was vaccinated only with adjuvants and in the broilers in control group. Indirect ELISA showed that the production of antibodies was high; therefore, the recombinant $\mathrm{F}$ protein has potential to be developed as a recombinant vaccine. Further efforts are still needed to eliminate the 6x His-tag from this recombinant $\mathrm{F}$ protein to obtain better antibody production. In addition, further studies are also needed to compare antibody production in broiler serum with several commercially available broiler vaccines.

\section{CONCLUSION}

Recombinant $\mathrm{F}$ protein of NDV from a local 
isolate (Galur, Kulon Progo, Indonesia) has been successfully expressed, purified and visualized via SDS-PAGE with Coomassie Brilliant Blue staining and western blotting and has been demonstrated to be a specific recombinant $\mathrm{F}$ protein with a molecular weight of $28 \mathrm{kDa}$. The broiler chickens group which were vaccinated by pure recombinant $\mathrm{F}$ protein showed the humoral immune response and the same anti-NDV antibodies production as the broiler chickens group which were vaccinated by available commercially inactive vaccines. Recombinant $F$ protein has the potential to be developed as a recombinant NDV vaccine candidate after truncating the $6 \mathrm{x}$ His-tag portion.

\section{ACKNOWLEDGMENTS}

Authors would like to thank the Head of Biochemistry Department, Faculty of Veterinary Medicine, Universitas Gadjah Mada, Yogyakarta and the Head of Institute of Inter University Centre for Biotechnology, Universitas Gadjah Mada, Yogyakarta for using their laboratory facilities and research materials to perform and complete this research. This research was supported by a research grant Penelitian Berbasis Kompetensi (PBK) fiscal year 2017-2018 from the Ministry of Research, Technology and Higher Education of Republic of Indonesia, grant number 2286/UN1.P.III/DIT-LIT/LT/2017.

\section{ETHICAL APPROVAL}

The research was approved by the ethics committee of the Faculty of Veterinary Medicine Universitas Gadjah Mada, Yogyakarta, Indonesia, No: 005/EC-FKH/Int./2018 (issued on March $\left.28^{\text {th }}, 2018\right)$.

\section{REFERENCES}

Alexander, D.J. 2004. Highly pathogenic avian influenza/Newcastle disease. In: OIE manual of diagnostic tests and vaccines for terrestrial animals. World Organisation for Animal Health, Paris, France. 258-282.

Alexander, D.J and D.A Senne. 2008. Newcastle disease, other avian paramyxoviruses, and pneumovirus infections. In Diseases of Poultry, $12^{\text {th }}$ ed. pp. $75-116$ Edited by Saif Y. M., Fadly A. M., Glisson J. R., McDougald L. R., Nolan L. K., Swayne D.
E., editors. Ames: Iowa State University Press

Alexander, D.J., R.J. Manvell, J. Banks, M.S. Collins, G. Parsons, B. Cox, K.M. Frost, E.C. Speidel, S. Ashman and E.W. Aldous. 1999. Experimental assessment of the pathogenicity of the Newcastle disease viruses from outbreaks in Great Britain in 1997 for chickens and turkeys and the protection afforded by vaccination. Avian Pathol. 28(5):501-511.

Arora, P., B.D. Lakhchaura and S. K. Garg. 2010. Evaluation of immunogenic potential of 75 $\mathrm{kDa}$ and $56 \mathrm{kDa}$ proteins of Newcastle disease virus (NDV). Indian J. Exp. Biol. 48(9):889-895.

Ashraf, A. and M.S. Shah. 2014. Newcastle Disease: Present status and future challenges for developing countries. African J. Microbiol. Res. 8(5):411-416.

Chimeno, Z.S, E. Gómez, E. Carrillo and A. Berinstein. 2008. Locally produced mucosal IgG in chickens immunized with conventional vaccines for Newcastle disease virus. Braz. J. Med. Biol. Res. 41(4):318-323.

Czifra, G., J. Meszaros, E. Horvath, V. Moving and B.E. Engstrom. 1998. Detection of NDV specific antibodies and the level of protection provided by a single vaccination in young chickens. Avian Pathol. 27(6): 562-565.

Elazab, M.F., Y. Fukushima, Y. Fujita, H. Horiuchi, H. Matsuda and S. Furusawa. 2010. Induction of immune suppression in the chick by an optimal dose of an immunizing antigen in the presence of its specific maternal antibody. J. Cent. Soc. Vet. Med. 72(3): 257-262.

El Zowalaty, M.E., Y. Chander, P.T. Redig, H.K. Abd El Latif, M.A El Sayed and SM. Goyal. 2011. Selective isolation of Avian influenza virus (AIV) from cloacal samples containing AIV and Newcastle disease virus. J. Vet. Diag. Invest. 23(2): 330-332.

Gaberc-Porekar, V. and V. Menart. 2001. Perspectives of immobilized-metal affinity chromatography. J. Biochem. Biophys. Methods. 49(1-3): 335-360.

Haryanto, A, M. Purwaningrum, S. Verawati, SH. Irianingsih and N. Wijayanti. 2015. Pathotyping of local isolates Newcastle Disease virus from field specimens by RT- 
PCR and restriction endonuclease analysis. Proc. Chem. 14:85-90.

Haryanto, A., R. Ermawati, V. Wati, N. Wijayanti. 2016a. Analysis of viral protein-2 encoding gene of avian encephalomyelitis virus from field specimen in Central Java region, Indonesia. Vet. World. 9(1): 25-31.

Haryanto, A. A. Wati and N. Wijayanti. 2016b. Molecular pathotyping of Newcastle disease virus from naturally infected chickens by RT-PCR and RFLP methods. Asian J. Anim. Sci. 10(1): 39-48.

Jeurissen SHM, Boonstra-Blom AG, Al-Garib SO, Hartog L and Koch G. 2000. Defence mechanisms against viral infection in poultry: A review. Vet. Q. 22(4): 204-208.

Kang, X., J. Wang, Y. Jiao, P. Tang, L. Song, D. Xiong and X. Jiao. 2016. Expression of recombinant Newcastle disease virus $F$ protein in Pichia pastoris and its immunogenicity using flagellin as the adjuvant. Prot. Exp. Pur. 128: 73-80.

Kapczynski, D.R. and D.J. King. 2005. Protection of chickens against overt clinical disease and determination of viral shedding following vaccination with commercially available Newcastle disease virus vaccines upon challenge with highly virulent virus from the California 2002 exotic Newcastle disease outbreak. Vaccine. 23(26):34243433.

Kattenbelt, J.A., M.P. Stevens and A.R. Gould. 2006. Sequence variation in the Newcastle disease virus genome. Virus Res. 116(1-2): 168-184.

Kumar, S., B. Nayak B, P.L. Collins and S.K. Samal. 2011. Evaluation of the Newcastle disease virus $\mathrm{F}$ and $\mathrm{HN}$ proteins in protective immunity by using a recombinant avian paramyxovirus type 3 vector in chickens. J. Virol. 85(13): 65216534.

Lamb, R.A. and T.S. Jardetzky. 2007. Structural basis of viral invasion: lessons from paramyxovirus F. Curr. Opin. Struct. Biol. 17(4):427-436.

Maheswarappa, G., K. Vijayarani, K. Kumanan and U.A. Kumar. 2014. Determination of Immune Potentials of Recombinant Fusion and Recombinant HaemagglutininNeuraminidase Antigens of Newcastle Disease Virus (NDV). J. Vet. Sci. Tech. 5(4):1-6.

Mase, M., K. Murayama, A. Karino and T. Inoue.
2011. Analysis of the fusion protein gene of Newcastle disease viruses isolated in Japan. J. Vet. Med. Sci. 73(1): 47-54.

Mayo. 2002a. A summary of taxonomic changes recently approved by ICTV. Arch. Virol. 147(8):1655-1663.

Mayo. 2002b. Virus taxonomy-Houston. Arch. Virol. 147(5):1071-1076.

Miller, P.J., L.M. Kim, H.P. Ip and C.L. Afonso. 2009. Evolutionary dynamics of Newcastle disease virus. Virol. 391(1):6472.

Miller, P.J., C.L. Afonso, J. El Attrache, K.M. Dorsey, S.C. Courtney, Z. Guo and D.R. Kapczynski. 2013. Effects of Newcastle disease virus vaccine antibodies on the shedding and transmission of challenge viruses. Develop. Comp. Immunol. 41(4): 505-513.

Mohan, C.M., S. Dey, A. Rai and J.M. Kataria. 2006. Recombinant haemagglutininneuraminidase antigen-based single serum dilution ELISA for rapid serological profiling of Newcastle disease virus. J. Virol. Methods. 138(1-2):117-122.

Muelemans, G., M. Gonze, M.C. Carlier, P. Petit, A. Burny and L. Le. 1986. Protective effects of $\mathrm{HN}$ and $\mathrm{F}$ glycoprotein specific monoclonal antibodies on experimental Newcastle disease. Avian Pathol. 15(4): 761-768.

Nagy, É, P.J. Krell, G.C. Dulac and J.B. Derbyshire. 1991. Vaccination against Newcastle disease with a recombinant baculovirus hemagglutinin-neuraminidase subunit vaccine. Avian Dis. 35(3):585-590.

Ogawa, R., N. Yanagida, S. Saeki, S. Saito, S. Ohkawa, H. Gotoh, K. Kodama, K. Kamogawa, K. Sawaguchi and Y. Iritani. 1990. Recombinant fowlpox viruses inducing protective immunity against Newcastle disease and fowlpox viruses. Vaccine. 8:486-490.

Ophardt, C.E. 2003. Denaturation of protein. Elmhurst College. Retriewed $16^{\text {th }}$ May 2020 from: http.//chemistry.elimhurst.ed/ vchembook.

Sambrook, J. and D.W. Russel. 2001. Molecular cloning, a laboratory manual. $3^{\text {rd }}$ Ed. Cold sping Harbor Laboratory Press. New York. 15.3 .

Stoker, H.S. 2010. General, organic, and biological chemistry. $5^{\text {th }}$ Ed. Cengage Learning: Belmont, CA USA. 684. 
Umino, Y., T. Kohama, T. Sato and A. Sugiura. 1990. Protective effect of monoclonal antibodies to Newcastle disease virus in passive immunization. J. Gen. Virol. 71(5): 1199-1203.

Westbury, H.A., Parsons and W.H. Allan. 1984. Comparison of the immunogenicity of Newcastle disease virus strains V4, Hitchner B1 and La Sota in chickens. 2. Tests in chickens with maternal antibody to the virus. Aus. Vet. Journal. 61(2):1013.

White, J.M., S.E Delos, M. Brecher and K. Schornberg. 2008. Structures and mechanisms of viral membrane fusion proteins: multiple variations on a common theme. Crit. Rev. Biochem. Mol. Biol. 43(3):189-219.

Wulanjati, M.P., N. Wijayanti and A. Haryanto. 2018. Phylogenetic analysis of Newcastle Disease virus from Indonesian isolates based on DNA-sequence of fusion proteinencoding gene. Biotechnol. 17(2):54-59.

Yin, H.S., X. Wen, R.G. Paterson, R.A. Lamb and T.S. Jardetzky. 2006. Structure of the parainfluenza virus $5 \mathrm{~F}$ protein in its metastable, prefusion conformation. Nature. 439(7072):38-44. 